\title{
Microscopic differential cell counting to identify inflammatory reactions in dairy cow quarter milk samples
}

\author{
R. Pilla, ${ }^{\star}$ D. Schwarz,† S. König, $\ddagger$ and R. Piccinini ${ }^{\star 1}$ \\ *Department of Veterinary Pathology, Hygiene and Public Health, Università degli Studi di Milano, Via Celoria 10, 20133 Milano, Italy \\ †Department of Animal Sciences, Institute of Veterinary Medicine, Division of Microbiology and Animal Hygiene, Faculty of Agricultural Sciences, \\ Georg-August-University Göttingen, Burckhardtweg 2, D-37077 Göttingen, Germany \\ ‡Department of Animal Breeding, University of Kassel, Nordbahnhofstraße 1a, D-37213 Witzenhausen, Germany
}

\begin{abstract}
The diagnosis of intramammary infections is mostly based on somatic cell count (SCC) and bacteriological analysis. As an alternative, differential cell counting (DCC) could be a useful method, because it identifies changes in the relative cell populations before the increase in total cell number occurs. The aim of the study was to identify cytological parameters that could be used in the field to classify mammary quarters as healthy or diseased, comparing cyto-bacteriological results with DCC. Overall, 48 cows were randomly selected from 3 herds in Lombardy region of Italy. Herd A was characterized by the absence of contagious microorganisms; in herds B and C, the prevalence of Staphylococcus aureus was 20 and $50 \%$, respectively. Foremilk samples were aseptically collected from 188 quarters and submitted to bacteriological analysis, SCC, and DCC. For statistical analysis, the samples were clustered into 4 health groups, and DCC results were compared in each group. Ninety-six samples were classified as normal secretions $(\mathrm{N}), 30$ as mastitis $(\mathrm{M}), 15$ as latent mastitis (LM), and 47 as unspecific mastitis (UM) based on SCC and bacteriological results. Single percentages of lymphocytes, polymorphonuclear neutrophilic leukocytes (PMNL), or macrophages were first evaluated to established variables capable of identifying healthy and inflamed quarters. Then, combinations of cell populations were tested to increase the discrimination power of DCC: phagocytes, logarithmic PMNL:lymphocyte ratio, and logarithmic phagocyte:lymphocyte ratio. The mean percentage of lymphocytes was significantly higher in group $\mathrm{N}$ than in groups LM, UM, and $\mathrm{M}$. The mean percentage of PMNL was significantly lower in group $\mathrm{N}$ than in groups UM and M, but not LM. Mean percentages of macrophages were not significantly influenced by the 4 groups. The mean value of phagocytes was significantly lower in group $\mathrm{N}$ than in the other groups.
\end{abstract}

Received January 11, 2012.

Accepted March 29, 2012.

${ }^{1}$ Corresponding author: renata.piccinini@unimi.it
Both the logarithmic PMNL:lymphocyte and the logarithmic phagocyte:lymphocyte ratios were significantly lower in group $\mathrm{N}$ than in groups LM, UM, and $\mathrm{M}$. Fisher $(F$-)values were calculated, and the highest $F$ value was that of log PMNL:lymphocytes ratio (48.23). The explanation for this could be that log PMNL:Lym is the only variable that involved both cell populations statistically influenced by health groups but excluded macrophages. Microscopic DCC has potential as a tool to identify cows affected by any inflammatory process of the mammary gland, with the best results being achieved using log PMNL:lymphocyte as variable.

Key words: differential cell count, subclinical mastitis, udder health, dairy cow

\section{INTRODUCTION}

Bovine mastitis is a major health problem in dairy cattle. Economic losses are mostly associated with decreased production and milk quality due to subclinical infections. Such infections are not evident and can persist in the mammary tissue throughout lactation. In the mammary gland, the number and distribution of leukocytes are important for the successful defense against invading pathogens (Leitner et al., 2003). Lymphocytes, macrophages, and PMNL play an important role in the inflammatory response within the mammary gland (Paape et al., 1979; Sordillo and Nickerson, 1988). Lymphocytes regulate the induction and suppression of immune responses (Nickerson, 1989), recognizing antigens through membrane receptors specific for invading pathogens (Sordillo et al., 1997). Macrophages are active phagocytic cells, capable of ingesting bacteria, cellular debris, and milk components (Sordillo and Nickerson, 1988). Milk or tissue macrophages recognize the invading pathogen and initiate an immune response by releasing chemoattractants that induce rapid recruitment of PMNL (Paape et al., 2002; Oviedo-Boyso et al., 2007). The main task of PMNL is to defend against invading bacteria at the beginning of acute inflammatory process (Paape et al., 1979; Oviedo-Boyso et al., 2007), when both the number and cellular activity of 
PMNL increase enormously (Targowski, 1983; Paape et al., 2003).

The presence of subclinical mastitis can be indicated by SCC and diagnosed by bacteriological analysis or PCR. Somatic cells consist of many cell types, including leukocytes and epithelial cells. Therefore, SCC is routinely used as a measure of inflammation based on the total number of cells in the milk sample. Bacteriological analysis gives the precise etiology of infection, but is time consuming and requires experienced personnel. Polymerase chain reaction has been proposed as an alternative to bacteriology as a rapid test (Koskinen et al., 2009) but it is expensive. At present, the diagnosis of bovine mastitis is mostly based on cyto-bacteriological analysis of milk samples (Vangroenweghe et al., 2002). The International Dairy Federation recommends the use of both SCC and bacteriological analysis as criteria for the determination of udder health (Hogan et al., 1999). The German Veterinary Society (DVG, 2002) suggests a threshold of $\leq 100,000$ cells $/ \mathrm{mL}$ to define a quarter as normal.

Staphylococcus aureus is a contagious pathogen and one of the most widely distributed causative agents of subclinical mastitis (International Dairy Federation, 2006). Environmental pathogens, mainly Streptococcus uberis and coliform bacteria, may enter the mammary gland, typically causing clinical mastitis. In the case of contagious pathogens, the prompt identification of infected animals is crucial to implement measures to avoid spread of the infection. Nevertheless, the detection of Staph. aureus can be difficult due to the intermittent shedding of the pathogen in milk (Sears et al., 1990) at levels frequently below the detection limit of the bacteriological method (Zecconi et al., 1997), and to the presence of persistent infections without an increase in SCC. Consequently, cyto-bacteriological analysis has only partial reliability, particularly when performed on a single sample (Schröder and Hamann, 2005). Identification of chronic mastitis caused by environmental pathogens also plays an important role in herd management, but it is often difficult due to the low numbers of bacteria shed in the milk (Hogan and Smith, 2003).

In healthy milk, the percentage of each cell type is widely variable; according to some authors, macrophages are the predominant cell type (Riollet et al., 2001; Lindmark-Mansson et al., 2006), whereas others have shown that lymphocytes are a major population (Park et al., 1992; Leitner et al., 2000a; Schwarz et al., 2011a,b). Moreover, cell percentages can vary depending on the milk fraction sampled, because cisternal milk shows a lower percentage of PMNL compared with alveolar milk (Sarikaya et al., 2005). Different cell pat- terns have been documented in the presence of different pathogens and during the course of infection (Leitner et al., 2000b). In addition to the etiological agent, the effect of lactation stage and parity number should be taken into account (Dosogne et al., 2003). In the presence of acute mastitis, PMNL are the predominant cell type, accounting for up to $90 \%$ of the total mammary leukocyte population (Sordillo and Streicher, 2002). In contrast, in chronic mastitis caused by Staph. aureus or CNS, the percentage of PMNL can be as low as that in uninfected quarters, whereas the percentage of macrophages is higher (Leitner et al., 2000b).

The changes in relative cell proportions can be considered a valid tool for the identification of inflammatory processes despite low SCC, thus differentiating healthy milk from that with early or late inflammation (Rivas et al., 2001). Recent studies (Schwarz et al., 2011a,b) have shown that differential cell counting (DCC) can reveal inflammatory processes even in milk with 9,000 cells/mL. Therefore, the goals of the present study were (1) to compare, in the field, cyto-bacteriological results with DCC results, and (2) to identify cytological parameters that could be used to classify mammary quarters as healthy or diseased.

\section{MATERIALS AND METHODS}

\section{Animals and Milk Sampling}

Three herds in the Lombardy region of Italy were enrolled in the study because they were participating in a voluntary control program for contagious or environmental pathogens. Herd A was characterized by the absence of contagious microorganisms; infections caused by Staph. aureus were present in the other 2 herds, with a lower prevalence in herd B (20\%) and a higher prevalence in herd C (approximately 50\%). All 3 herds housed Holstein-Friesian cows (120 in herd A, 180 in herds B and C) in freestalls, and cows were milked twice daily in a milking parlor.

Overall, 48 cows were randomly selected, of which 23 cows were primiparous, 11 were in the second or third lactation, and 14 had calved 4 or more times. Eleven animals were in early lactation ( 8 to $86 \mathrm{~d}$ ), 20 were in mid lactation (96 to $210 \mathrm{~d}$ ), and 17 were in late lactation (247 to $531 \mathrm{~d}$ ). All cows were free of clinical signs of mastitis at sampling.

After cleaning and disinfection of the teat, the first 2 squirts of milk were discarded, and $10 \mathrm{~mL}$ of foremilk was aseptically collected from 188 quarters in sterile plastic tubes (Bioster, Seriate, Italy). Samples were kept under refrigeration until arrival at laboratory facilities. 


\section{SCC and Bacteriological Analysis}

All samples were submitted to bacteriological analysis, which was performed as previously described (Oliver et al., 2004). Briefly, a 10- $\mu \mathrm{L}$ aliquot of each sample was spread onto blood agar plates $(5 \%$ bovine blood, Oxoid, Basingstoke, UK) and incubated at $37^{\circ} \mathrm{C}$. Plates were evaluated after 24 and $48 \mathrm{~h}$, and colonies of growth were isolated. The large and hemolytic colonies that were catalase- and coagulase-positive were identified as Staph. aureus and thereafter confirmed by API ID32 Staph (bioMérieux, Marcy l'Etoile, France). All the other colonies were identified by biochemical tests following Hogan et al. (1999). Somatic cells were counted on a Bentley Somacount 150 (Bentley Instruments, Chaska, MN).

\section{DCC}

Slides for DCC were prepared following Dulin et al. (1982), with modified centrifugation conditions. Briefly, for each sample, an aliquot of $4 \mathrm{~mL}$ was diluted with $10 \mathrm{~mL}$ of PBS with $0.5 \%$ EDTA (PBS-EDTA). Samples were then centrifuged at $125 \times g$ for $15 \mathrm{~min}$, and cell pellets were resuspended in PBS-EDTA. Cell suspensions were centrifuged on a cytocentrifuge (Shandon Cytospin, Thermo Scientific, Waltham, MA) at $20 \times g$ for 5 min. Slides were air-dried and stained with May Grünwald-Giemsa stain. Each slide was evaluated by light microscopy, and 100 to 200 cells were differentiated into lymphocytes, macrophages, and PMNL, according to standard methods (Coles, 1974; Lee et al., 1980). Epithelial cells could not always be distinguished from macrophages and therefore were counted as macrophages.

\section{Statistical Analysis}

For the statistical analysis, the 188 milk samples were clustered into 4 health groups according to Bansal et al. (2005). The first group included quarters considered as normal secreting $(\mathbf{N})$, with $\mathrm{SCC} \leq 100,000$ cells $/ \mathrm{mL}$ and no pathogens. The second group included quarters with latent mastitis (LM), characterized by SCC $\leq 100,000$ cells $/ \mathrm{mL}$ and a positive bacteriological culture. The third group was classified as unspecific mastitis (UM), including quarters with SCC $>100,000$ cells $/ \mathrm{mL}$ and culture-negative results. The fourth group was considered as affected by mastitis $(\mathbf{M})$, including culture-positive quarters with SCC $>100,000$ cells $/ \mathrm{mL}$.

The effect of the 4 health groups on individual cell populations was analyzed by applying linear mixed models and using the SAS program (version 9.1, SAS
Institute Inc., Cary, NC). The statistical model (model [1]) was defined as follows:

$$
\begin{array}{r}
y_{i j k l m n}=\mu+\text { herd }_{i}+\text { parity }_{j}+\text { DIM }_{k}+\text { cow }_{l}+\text { group }_{m} \\
+ \text { quarter }_{n}+e_{i j k l m n},
\end{array}
$$

where $y_{i j k l m n}=$ observation for the individual cell population of cow $l, \mu=$ overall mean effect, $\operatorname{herd}_{i}=$ fixed effect of the $i$ th herd of cow $l$, parity $y_{j}=$ fixed effect of the $j$ th parity of cow $l, D I M_{k}=$ fixed effect of the $k$ th class of days in milk, $c o w_{l}=$ random effect of cow $l$,

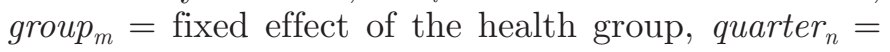
fixed effect of the position of the udder quarter, and $e_{i j k l m n}=$ random residual effect.

For a second analysis, udder quarters were classified into 2 categories: healthy and diseased. Healthy udder quarters were assigned a score of 0 and consisted of group N, whereas diseased udder quarters (group D) were assigned a score of 1 and included groups LM, UM, and M. Because the defined disease was treated as a binary trait, a logistic model was applied to assess the effect of individual cell populations on the occurrence of the disease. Analysis of variance was carried out using logistic models as implemented in the SAS Glimmix macro (Wolfinger and O'Connell, 1993). Significance of regression coefficients of was determined by using results from sum of square type I tests (Wald-type tests) and $F$-statistics. The final generalized linear model (model [2]) used to determine the effect of fixed effects and covariates on the incidence of the disease was

$$
\begin{aligned}
\operatorname{logit}\left(\pi_{r s t u}\right) & =\log \left[\frac{\pi_{r s t u}}{1-\pi_{r s t u}}\right]=\eta_{r s t} \\
& =\varphi+\gamma_{r}+\lambda_{s}+\tau_{t}+v_{u}+\varphi_{v}+b_{1} Y_{r s t u}
\end{aligned}
$$

where $\pi_{r s t u}=$ probability of occurrence of the disease, $\varphi$ $=$ overall mean effect, $\gamma_{r}=$ fixed effect of parity, $\lambda_{s}=$ fixed herd effect, $\tau_{t}=$ fixed effect of the position of the udder quarter, $v_{u}=$ fixed effect for classes of DIM, $\varphi_{v}$ $=$ random effect of the cow, $Y_{r s t u}=$ value for the individual cell population, and $b_{1}=$ linear regression of the disease on the value of the individual cell population.

\section{RESULTS}

\section{SCC and Bacteriological Analysis}

Foremilk samples were taken from 188 quarters of 48 cows in 3 Italian dairy farms. Overall, 92 samples (48.4\%) were classified as diseased. In herd A, out of 70 samples tested, 59 (84.3\%) were bacteriologically nega- 
tive, and only 1 showed a major pathogen, Escherichia coli. In addition, CNS were detected in 5 samples, Enterococcus faecalis in 4, and Streptococcus dysgalactiae in 1 sample. In herd B, 57 out of 78 quarters tested $(73.1 \%)$ were bacteriologically negative, whereas 13 (16.6\%) were positive for Staph. aureus. Four samples showed the presence of CNS, and a further 4 samples were considered contaminated. Finally, in herd C, 25 out of 40 quarters tested (62.5\%) were bacteriologically negative, whereas $10(25 \%)$ were positive for Staph. aureus; CNS were detected in 3 samples, and Ent. faecalis in 1 sample.

The clustering of milk samples into the 4 health groups is summarized in Table 1. Following group definitions (Bansal et al., 2005), 96 quarters belonged to group $\mathrm{N}$ (normal secretion), and 30 samples were categorized into group M (mastitis). Out of them, 18 samples showed Staph. aureus and 6 samples CNS; Strep. dysgalactiae was detected in 1 sample, and Ent. faecalis in 5 samples. A further 15 samples were classified in group LM (latent mastitis): CNS were detected in 7 samples, Staph. aureus in 5 samples, E. coli in 1 sample, and contamination in 2 samples. Group UM (unspecific mastitis) included 47 samples.

\section{DCC}

The DCC of all quarter foremilk samples analyzed was determined by microscopic differentiation of 100 to 200 cells into lymphocytes, macrophages, and PMNL. In addition to the percentages of individual cell populations, the following variables were considered: phagocytes (Phag, combining macrophages and PMNL), logarithmic PMNL:lymphocyte ratio (log PMNL:Lym), and logarithmic phagocytes:lymphocyte ratio (log Phag:Lym), which involved all 3 cell populations.
Overall ( $\mathrm{n}=188$ samples), the proportion of lymphocytes ranged between 1 and $97 \%$, with a mean of $25 \%$ (SD 23.2\%), that of macrophages ranged between 0 and $80 \%$ with a mean of $19.2 \%$ (SD 16.9\%), and proportions of PMNL ranged between 0 and $96 \%$ with a mean of $55.8 \%$ (SD 25.8\%).

Mean values and standard deviation for each variable considered in each farm are summarized in Table 2. Mean percentages of PMNL were 58.7, 67.0, and $31.8 \%$ in herds A, B, and C, respectively. Mean percentages of lymphocytes showed similar values in the 3 herds $(29 \%$ in A, $20 \%$ in B, and $25.6 \%$ in C). Mean percentages of macrophages were almost identical in herds $\mathrm{A}$ and $\mathrm{B}$ (12.3 and $12.9 \%$, respectively), whereas herd $\mathrm{C}$ showed a much higher mean value (42.6\%). Mean percentages of phagocytes were similar in all herds $(71 \%$ in A, $79.9 \%$ in $\mathrm{B}$, and $74.4 \%$ in $\mathrm{C}$ ), whereas the mean values of $\log$ PMNL:Lym and log Phag:Lym were higher in herd B compared with those in herds A and $\mathrm{C}$ (0.40 and 0.50 in herd A, 0.73 and 0.81 in herd $\mathrm{B}, 0.22$ and 0.59 in herd C, respectively).

The variance analysis indicated that percentages of all individual cell populations were significantly $(P<$ 0.01 ) influenced by farm, and macrophages were further significantly $(P<0.01)$ influenced by DIM. None of the individual cell populations was influenced by quarter position or lactation number (Table 3 ). The variables Phag, log Phag:Lym, and log PMNL:Lym were significantly $(P<0.01)$ influenced by farm but not by quarter position, lactation number, or DIM (Table 2). Overall, a significant $(P<0.0001)$ effect of the 4 health groups was demonstrated on percentages of lymphocytes and PMNL, but not on macrophages (Table 3).

The mean percentage of lymphocytes in group $\mathrm{N}$ $(34.5 \%)$ was significantly $(P<0.05)$ higher than in groups LM, UM, and M $(23.3,15.9$, and $11.3 \%$, re-

Table 1. Clustering of milk samples into the 4 health groups according to Bansal et al. (2005), with bacteriological results and SCC

\begin{tabular}{|c|c|c|c|c|c|c|}
\hline Group $^{1}$ & $\begin{array}{l}\text { No. of } \\
\text { quarters }\end{array}$ & $\begin{array}{l}\text { Bacteriologic } \\
\text { result }\end{array}$ & Bacteria isolated & $\begin{array}{l}\text { No. of } \\
\text { quarters }\end{array}$ & $\begin{array}{l}\mathrm{SCC}, \times 1,000 \\
\quad \text { cells } / \mathrm{mL}\end{array}$ & $\begin{array}{l}\mathrm{SCC}, \times 1,000 \text { cells } / \mathrm{mL} \\
(\text { mean } \pm \mathrm{SEM})\end{array}$ \\
\hline $\mathrm{N}$ & 96 & No growth & & & & $19.62 \pm 2.50$ \\
\hline \multirow{3}{*}{ LM } & & & Staphylococcus aureus & 5 & $9-93$ & $56.20 \pm 19.16$ \\
\hline & & & Escherichia coli & 1 & 42 & $42 \pm 0$ \\
\hline & & & Contaminated & 2 & $72-83$ & $77.50 \pm 5.50$ \\
\hline \multirow[t]{4}{*}{ M } & 30 & Positive & $\mathrm{CNS}$ & 6 & $132-2,783$ & $763.50 \pm 412.73$ \\
\hline & & & Staph. aureus & 18 & $122-1,625$ & $585.11 \pm 114.06$ \\
\hline & & & Streptococcus dysgalactiae & 1 & 679 & $679 \pm 0$ \\
\hline & & & Enterococcus faecalis & 5 & $350-4,725$ & $1,367.80 \pm 840.58$ \\
\hline
\end{tabular}

${ }^{1} \mathrm{~N}=$ normal secretion; $\mathrm{LM}=$ latent mastitis; $\mathrm{UM}=$ unspecific mastitis; $\mathrm{M}=$ mastitis. 
Table 2. Mean values and standard deviation for the percentage of individual cell populations and combinations of cell populations in farms A, B, and C

\begin{tabular}{|c|c|c|c|c|c|c|}
\hline \multirow{2}{*}{$\begin{array}{l}\text { Cell population } \\
\text { or variable }^{1}\end{array}$} & \multicolumn{2}{|c|}{$\mathrm{A}$} & \multicolumn{2}{|c|}{ B } & \multicolumn{2}{|c|}{$\mathrm{C}$} \\
\hline & Mean & SD & Mean & SD & Mean & $\mathrm{SD}$ \\
\hline PMNL, \% & 58.68 & 23.10 & 67.03 & 21.11 & 31.79 & 21.05 \\
\hline Lymphocytes, \% & 28.97 & 23.56 & 20.05 & 22.09 & 25.56 & 22.34 \\
\hline Macrophages, \% & 12.35 & 9.06 & 12.92 & 8.38 & 42.65 & 18.06 \\
\hline Phag, \% & 71.03 & 23.56 & 79.95 & 22.09 & 74.44 & 22.34 \\
\hline Log PMNL:Lym & 0.40 & 0.63 & 0.73 & 0.65 & 0.22 & 0.65 \\
\hline Log Phag:Lym & 0.50 & 0.61 & 0.81 & 0.62 & 0.59 & 0.52 \\
\hline
\end{tabular}

${ }^{1}$ Phag = phagocytes (macrophages and PMNL); log PMNL:Lym = logarithmic PMNL:lymphocyte ratio; log

Phag:Lym = logarithmic phagocyte/lymphocyte ratio.

spectively; Figure 1), and the value in group LM was significantly $(P<0.05)$ higher than that in group M. Mean percentage of PMNL was significantly $(P<0.01)$ lower in group $\mathrm{N}(42.2 \%)$ than in groups $\mathrm{UM}$ and $\mathrm{M}$ $(62.3 \%$ and $67.9 \%$, respectively; Figure 1); in addition, the value in group LM $(54.9 \%)$ was significantly $(P<$ 0.05 ) lower than that in group M. Finally, mean percentages of macrophages were not significantly related to the 4 groups (N: $23.3 \%$; LM: $21.5 \%$; UM: $21.7 \%$; M: $20.6 \%$; Figure 1).

All variables combining different cell populations were significantly $(P<0.001)$ influenced by health group (Table 3 ). The mean value of Phag was significantly lower $(P<0.05)$ in group $\mathrm{N}(65.5)$ than in groups LM, UM, and M (76.7, 84.1, and 88.6, respectively; Figure $2)$. In addition, the value in group LM was significantly $(P<0.05)$ lower than that in group $\mathrm{M}$.

The log PMNL:Lym mean value in group $\mathrm{N}(0.11)$ was significantly $(P<0.001)$ lower than in groups LM, $\mathrm{UM}$, and $\mathrm{M}(0.57,0.73$, and 0.94 , respectively; Figure $3)$, and the value in group LM was significantly $(P<$ 0.05 ) lower than that in group M (Figure 3 ).

Finally, log Phag:Lym showed a significantly $(P<$ $0.01)$ lower value in group $\mathrm{N}(0.35)$ than in groups LM, $\mathrm{UM}$, and $\mathrm{M}(0.73,0.91$, and 1.06 , respectively; Figure
4). Group $M$ also demonstrated a significantly higher $(P<0.05)$ mean value than group LM (Figure 4).

The possibility of differentiating between healthy and diseased udder quarters was further evaluated using individual cell populations as well as the variables that combined different cell populations. For this purpose, quarters were split into 2 groups and $F$-values were calculated. The first group (N) included all healthy quarters $(\mathrm{n}=96)$, whereas the second group $(\mathrm{D}, \mathrm{n}=$ 92) included diseased mammary quarters (groups LM, $\mathrm{UM}$, and M). Out of the 3 individual cell populations, lymphocytes best differentiated between groups $\mathrm{N}$ and D (Table 4). Although macrophages showed an $F$-value of 1.65 and did not differ significantly between group $\mathrm{N}$ and D, the $F$-value of PMNL (15.54) was higher and significantly $(P<0.001)$ different (Table 4$)$. Nevertheless, lymphocytes showed the highest $F$-value (32.64) and their percentage differed significantly between group $\mathrm{N}$ and $\mathrm{D}(P<0.0001)$.

All cell combinations allowed us to differentiate significantly $(P<0.001)$ between groups $\mathrm{N}$ and $\mathrm{D}$. Nevertheless, the highest $F$-value was shown by log PMNL:Lym (48.23), whereas Phag and log Phag:Lym showed $F$-values of 32.64 and 45.90 , respectively (Table $4)$.

Table 3. Results of variance analysis for the percentage of individual cell populations as well as combinations of cell populations in 188 quarter foremilk samples analyzed by light microscopy ${ }^{1}$

\begin{tabular}{llccll}
\hline $\begin{array}{l}\text { Cell population } \\
\text { or variable }^{2}\end{array}$ & Group & $\begin{array}{c}\text { Quarter } \\
\text { position }\end{array}$ & $\begin{array}{c}\text { Lactation } \\
\text { number }\end{array}$ & DIM & Farm \\
\hline PMNL & 0.0001 & 0.07 & 0.16 & 0.27 & 0.0001 \\
Lymphocytes & 0.0001 & 0.22 & 0.09 & 0.07 & 0.005 \\
Macrophages & 0.66 & 0.52 & 0.75 & 0.009 & 0.0001 \\
Phag & 0.0001 & 0.22 & 0.09 & 0.07 & 0.005 \\
Log PMNL/Lym & 0.0001 & 0.08 & 0.13 & 0.52 & 0.0001 \\
Log Phag/Lym & 0.0001 & 0.09 & 0.11 & 0.36 & 0.0007 \\
\hline
\end{tabular}

${ }^{1}$ Analyzed factors were group (normal secretion, latent mastitis, unspecific mastitis, mastitis), quarter position (front right, rear right, front left, and rear left), lactation number $(1,2,3, \geq 4)$, DIM (8-86 d, 96-210 d, 247-531 d), and farm (A to C).

${ }^{2}$ Phag $=$ phagocytes (macrophages and PMNL); log PMNL:Lym = logarithmic PMNL:lymphocyte ratio; log Phag:Lym = logarithmic phagocyte/lymphocyte ratio. 


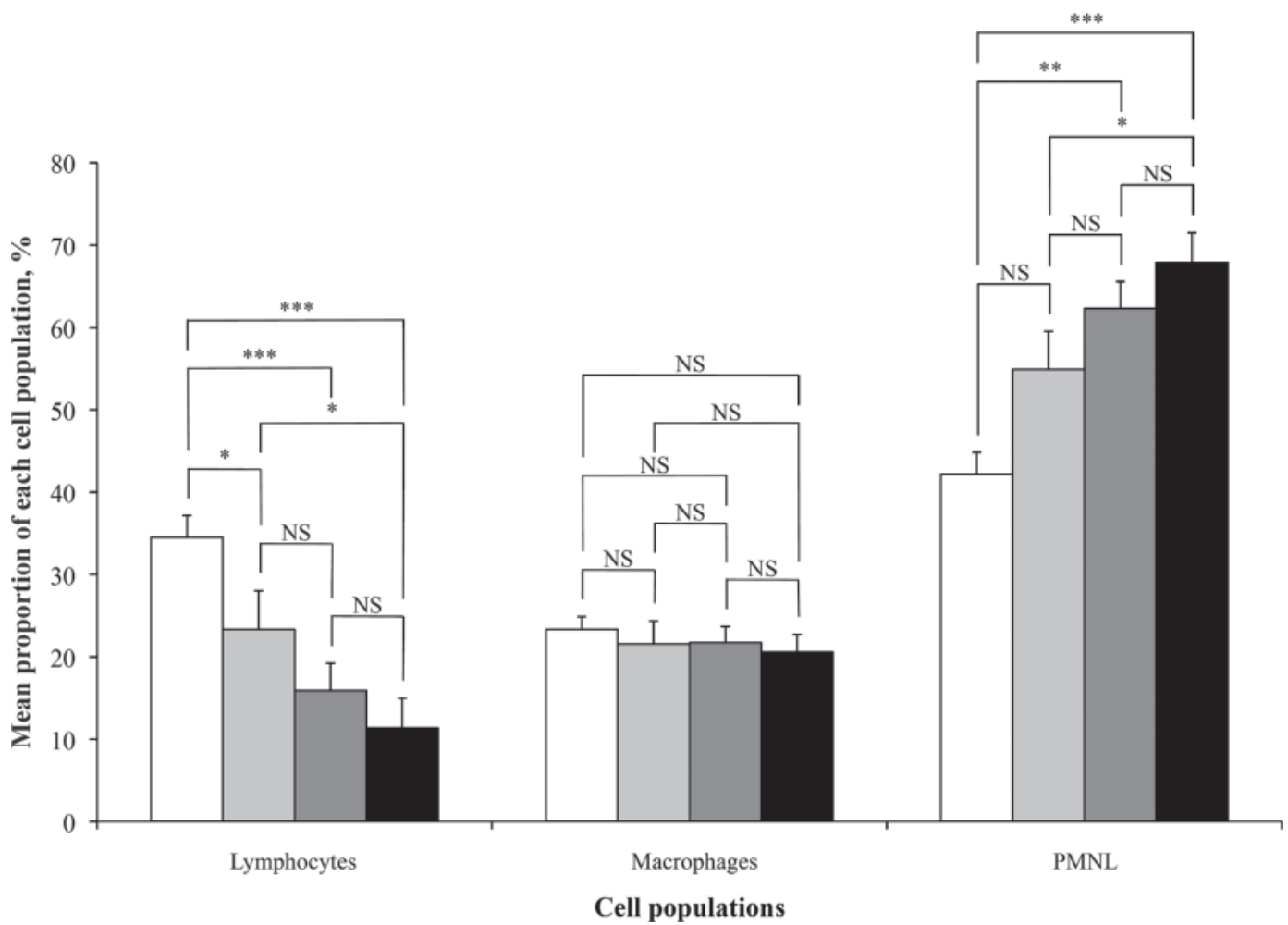

Figure 1. Comparison of mean percentages of lymphocytes, macrophages, and PMNL in milk of udder quarters with different health status. All 188 udder quarters analyzed were classified into groups N, LM, UM, and M (group N = empty bars, SCC $\leq 100,000$ cells/mL and culturenegative, $\mathrm{n}=96$; group $\mathrm{LM}=$ light gray bars, $\mathrm{SCC} \leq 100,000$ cells $/ \mathrm{mL}$ and culture-positive, $\mathrm{n}=15$; group UM = dark gray bars, $\mathrm{SCC}>100,000$ cells $/ \mathrm{mL}$ and culture-negative, $\mathrm{n}=47$; group $\mathrm{M}=$ black bars, $\mathrm{SCC}>100,000$ cells $/ \mathrm{mL}$ and culture-positive, $\mathrm{n}=30$ ). $\mathrm{N}=$ normal secretion; LM $=$ latent mastitis; $\mathrm{UM}=$ unspecific mastitis; $\mathrm{M}=$ mastitis. Data are expressed as mean $\pm \mathrm{SEM}$ for percentages of the individual cell populations in the 4 SCC groups defined; ${ }^{* * *} P<0.001 ;{ }^{* *} P<0.01 ;{ }^{*} P<0.05 ;$ NS $=P>0.05$.

\section{DISCUSSION}

The diagnosis of IMI is mostly based on SCC and bacteriological analysis. Milk samples with SCC $<100,000$ cells $/ \mathrm{mL}$ are currently considered healthy or within normal physiological limits, but inflammatory reactions can be detected in such samples (Schwarz et al., 2011a,b). Indeed, SCC is low in the initial stage of inflammatory reaction, until the invading pathogen is recognized by immune and epithelial cells that release chemoattractants, thus stimulating migration of PMNL (Paape et al., 2002; Oviedo-Boyso et al., 2007; Koess and Hamann, 2008). Differential cell count could be a useful method, because it identifies changes in the relative cell populations before the increase in total cell number occurs in the course of the inflammatory process. Therefore, DCC could be regarded as the standard technique to determine the presence or absence of inflammation in mammary quarters (Rivas et al., 2001).

The aim of the present study was to detect one or more parameters that could easily identify diseased mammary quarters independently of the prevalent pathogen in the herd using light microscopy DCC. Differential cell count can be performed with either flow cytometry or light microscopy. Cytometric analysis is a very accurate method, but expensive and time-consuming, because it is based on the use of several marker antibodies. Leitner et al. (2000b) reported a high correlation between flow cytometry and light microscopy for PMNL and lymphocytes, but a lower correlation for macrophages and epithelial cells. This lower correlation could be due to the difficult differentiation between macrophages and epithelial cells by light microscopy. Epithelial cells are not always present in the milk (Lee et al., 1980) or they make up only 1 to $3 \%$ of cells (Sarikaya et al., 2004; Schwarz et al., 2011a). Different results were reported by Miller et al. (1991) and Leitner et al. (2000b), who recorded higher values (10 to $19 \%$ or $44 \%$, respectively). Miller et al. (1991) sampled only primiparous cows in early lactation, whereas Leitner et al. (2000b) evaluated epithelial cell percentages using a nonspecific identification procedure. However, according to Schwarz et al. (2011a), percentages $>10 \%$ should 


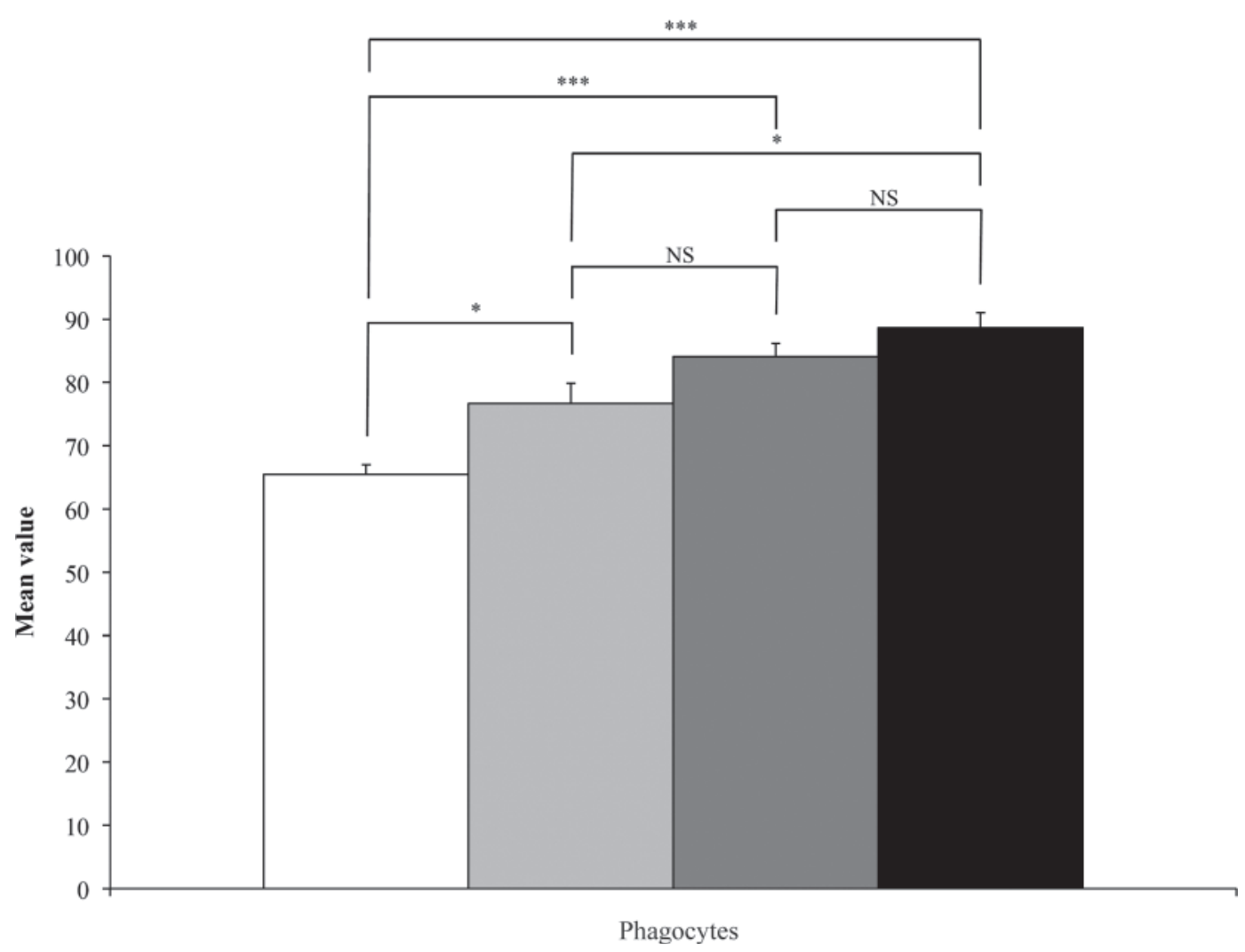

Figure 2. Comparison of mean values of phagocytes (macrophages and PMNL) in milk of udder quarters with different health status. All 188 udder quarters analyzed were classified into groups N, LM, UM, and M (group N = empty bars, SCC $<100,000$ cells/mL and culture-negative, $\mathrm{n}=96$; group $\mathrm{LM}=$ light gray bars, $\mathrm{SCC} \leq 100,000$ cells/mL and culture-positive, $\mathrm{n}=15$; group $\mathrm{UM}=$ dark gray bars, $\mathrm{SCC}>100,000$ cells/ $\mathrm{mL}$ and culture-negative, $\mathrm{n}=47$; group $\mathrm{M}=$ black bars, $\mathrm{SCC}>100,000$ cells $/ \mathrm{mL}$ and culture-positive, $\mathrm{n}=30) . \mathrm{N}=$ normal secretion; $\mathrm{LM}=$ latent mastitis; $\mathrm{UM}=$ unspecific mastitis; $\mathrm{M}=$ mastitis. Data are expressed as mean $\pm \mathrm{SEM} ; * * * P<0.001 ;{ }^{*} P<0.05 ; \mathrm{NS}=P>0.05$.

be critically discussed. Therefore, the misclassification of epithelial cells likely represents a minor error that probably does not affect the result. For these reasons, light microscopy DCC is a suitable method applicable to routine analysis. It is cost effective and could be automated by using a slide scanner and computer imaging software.

Three dairy herds were selected with different prevalences of IMI, which were caused by different etiological agents. The influence of breed was not explored because all 3 herds housed Holstein-Friesian cows. The causative agents of mastitis were environmental pathogens in herd A but contagious bacteria in the other 2 herds. Moreover, Staph. aureus isolates from herds B and C demonstrated low and high diffusiveness, respectively. The results of DCC showed statistically significant differences among the 3 herds considered, as expected and in accordance with previous reports (Schwarz et al., 2011b). The DCC results in herds A and B showed relative higher values of PMNL followed by lymphocytes and macrophages, whereas macrophages were the main population in herd $\mathrm{C}$, followed by PMNL and lymphocytes. These data suggest that most infections in herds $\mathrm{A}$ and $\mathrm{B}$ were acute infections, with high increases of PMNL, whereas herd C probably had a considerable prevalence of chronic infections, which led to an increase in macrophage percentage, as also shown by Sladek and Rysanek (2009).

No correlation was found between cell populations and either quarter position or lactation number, in accordance with findings described by Schwarz et al. (2011a,b). Dosogne et al. (2003) reported the effect of DIM on DCC in the milk, showing that lymphocytes decreased while PMNL and macrophages increased in the course of lactation. In contrast, our data indicated that only macrophages were influenced by DIM. This discrepancy could be related to the different methods used, because the analyses of Dosogne et al. (2003) were performed by flow cytometer. Despite this, the results of the present study could not bias quarter classification by DCC, because macrophages were the only population not significantly influenced by health group. Even 


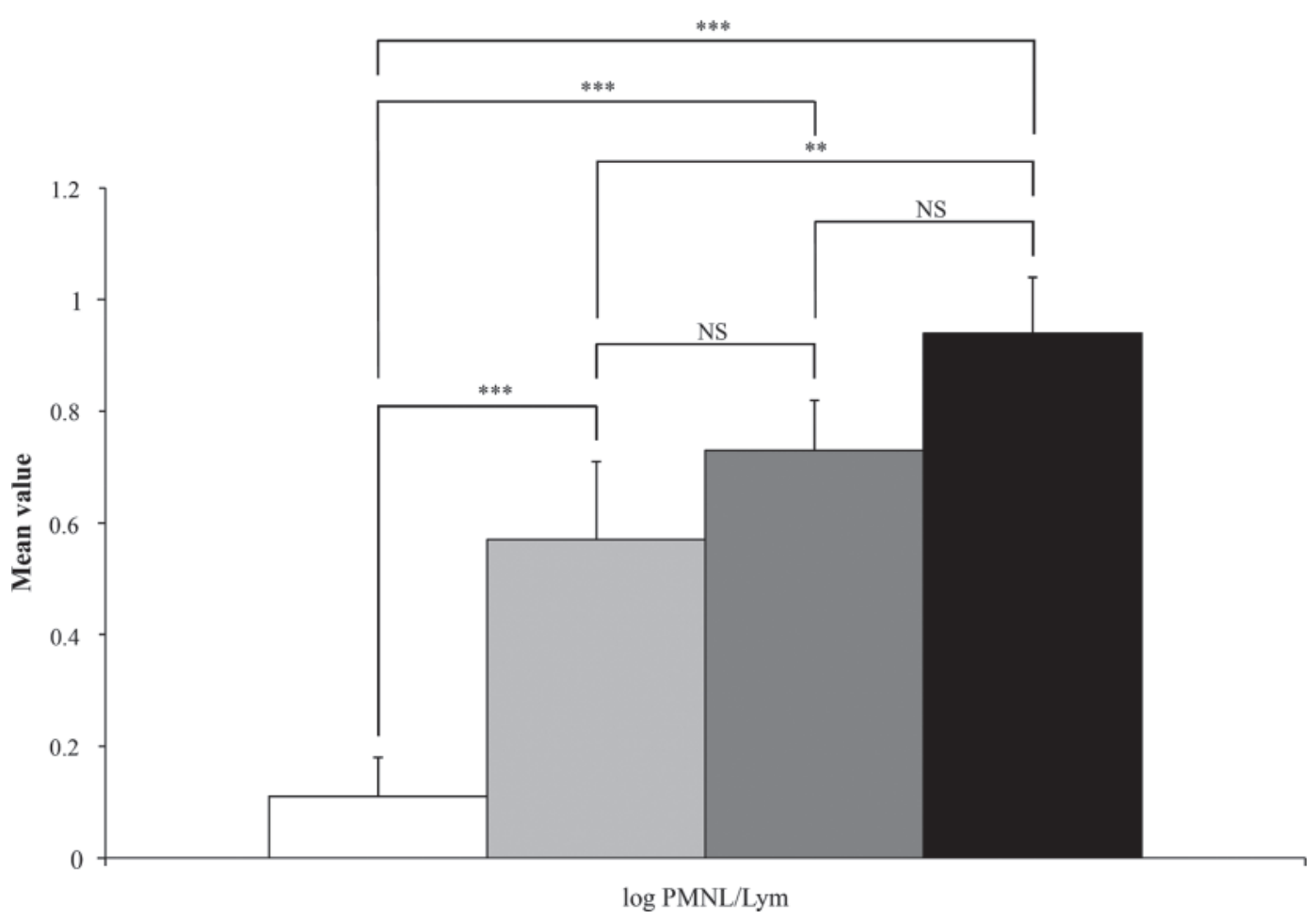

Figure 3. Comparison of mean values of the variable log PMNL/Lym (logarithmic PMNL:lymphocyte ratio) in milk of udder quarters with different health status. All 188 udder quarters analyzed were classified into groups A to D (group A = empty bars, SCC $\leq 100,000$ cells/ $\mathrm{mL}$ and culture-negative, $\mathrm{n}=96$; group $\mathrm{B}=$ light gray bars, $\mathrm{SCC} \leq 100,000$ cells $/ \mathrm{mL}$ and culture-positive, $\mathrm{n}=15$; group $\mathrm{C}=$ dark gray bars, SCC $>100,000$ cells $/ \mathrm{mL}$ and culture-negative, $\mathrm{n}=47$; group $\mathrm{D}=$ black bars, $\mathrm{SCC}>100,000$ cells $/ \mathrm{mL}$ and culture-positive, $\mathrm{n}=30$ ). Data are expressed as mean $\pm \mathrm{SEM} ;{ }^{* * *} P<0.001 ;{ }^{* *} P<0.01 ; \mathrm{NS}=P>0.05$.

though 2 recent publications (Schwarz et al., 2011a,b) indicated that inflammatory profiles can be found in quarters with $\mathrm{SCC}<100,000$ cells $/ \mathrm{mL}$, we decided to follow the current recommendations of DVG (2002) to enable comparisons between cyto-bacteriological and DCC results. In fact, Harmon (1994) showed that losses in production occur starting at 100,000 cells/mL, and Pyörälä (2003) stated that milk components differ significantly from the physiological norm above this level. Interestingly, 15 milk samples in group $\mathrm{N}$ showed marked inflammatory profiles, with PMNL percentages $>80 \%$; in particular, one quarter showed an SCC value of 1,000 cells/mL and 91.3\% PMNL. Many factors could explain the high percentage of PMNL in these quarters, including chemical and mechanical factors or physical injury. Furthermore, any of these quarters could show false negative results on bacteriological analysis, for different reasons. Negative bacteriological results could depend on intermittent shedding of pathogens or shedding in amounts lower than the detection limit of the method applied or on the presence of antimicrobials in milk (Sears et al., 1990; Zecconi et al., 1997). It is also possible that the inflammatory response was so effec- tive in those quarters that most bacteria were phagocytosed and killed, or survived only intracellularly by active invasion of cells or survival inside phagosomes (Newbould and Neave, 1965; Hill et al., 1978). Furthermore, in the UM quarters, inflammatory processes were present, even in the absence of bacteria, as indicated by increased SCC and high PMNL percentages. Because cellular profiles were similar in groups UM and M, with no significant difference, it could be hypothesized that some UM samples were false negatives.

Of the 3 cell populations, PMNL are known to strongly increase during the course of infection and have been consistently reported as the dominant cell population in mastitic milk (Kehrli and Shuster, 1994; Sordillo et al., 1997; Pillai et al., 2001). Therefore, PMNL would be an obvious choice to differentiate between healthy and infected quarters with low SCC. Accordingly, PMNL were statistically lower in group $\mathrm{N}$ than in groups $\mathrm{UM}$ and $\mathrm{M}$, but no difference was demonstrated between groups $\mathrm{N}$ and LM. The macrophage percentage was very similar in the 4 groups, because macrophages are associated with the late phase of infection (Leitner et al., 2000b; Sladek and Rysanek, 2009) and are expected 
Table 4. Fisher $(F)$-values and associated probabilities of different markers to discriminate between healthy (group $\mathrm{N} ; \mathrm{n}=96$ ) and diseased (group D, including groups LM, UM, M; $\mathrm{n}=92$ ) udder quarters $^{1}$

\begin{tabular}{lrr}
\hline Marker $^{2}$ & $F$-value & $P$-value \\
\hline PMNL, \% & 15.54 & 0.0001 \\
Lymphocytes, \% & 32.64 & $<0.0001$ \\
Macrophages, \% & 1.65 & 0.2007 \\
Phag, \% & 32.64 & $<0.0001$ \\
Log PMNL:Lym & 48.23 & $<0.0001$ \\
Log Phag:Lym & 45.90 & $<0.0001$ \\
\hline
\end{tabular}

${ }^{1} \mathrm{~N}=$ normal secretion; $\mathrm{LM}=$ latent mastitis; $\mathrm{UM}=$ unspecific mastitis; $\mathrm{M}=$ mastitis.

${ }^{2}$ Phag $=$ phagocytes (macrophages and PMNL); log PMNL:Lym = logarithmic PMNL:lymphocyte ratio; log Phag:Lym = logarithmic phagocyte/lymphocyte ratio.

to increase in chronic infections, which were presumably at low levels in the cows of this study. Lymphocytes were the only individual cell population showing statistically different percentages between the healthy group and all diseased groups. Mammary lymphocytes play an important role in the initiation of immune response of the gland. They are mainly $\mathrm{T}$ cells, whose function is to remove old and damaged secretory cells, thus decreasing the susceptibility of the mammary gland to infections (Sordillo et al., 1997).

Combinations of cell populations were evaluated to increase the discrimination power of DCC. Indeed, combining populations increased the $F$-values, indicating that a larger percentage of quarters would be correctly classified when that parameter was considered. Combining PMNL and macrophages into phagocytes (Phag variable) increased $F$-values from 1.65 and 15.54, respectively, to 32.64. Combining PMNL and lymphocytes into the log PMNL:Lym ratio increased $F$-values from 15.54 and 32.64 to 48.23 , and the combination of Phag and Lym into the log Phag:Lym ratio, which includes all 3 cell populations, led to an $F$-value of 45.90. All combinations of individual cell populations showed statistically significant differences between groups $\mathrm{N}$ and $\mathrm{D}$, but the best $F$-value was related to $\log$ PMNL:Lym, presumably because log PMNL:Lym was

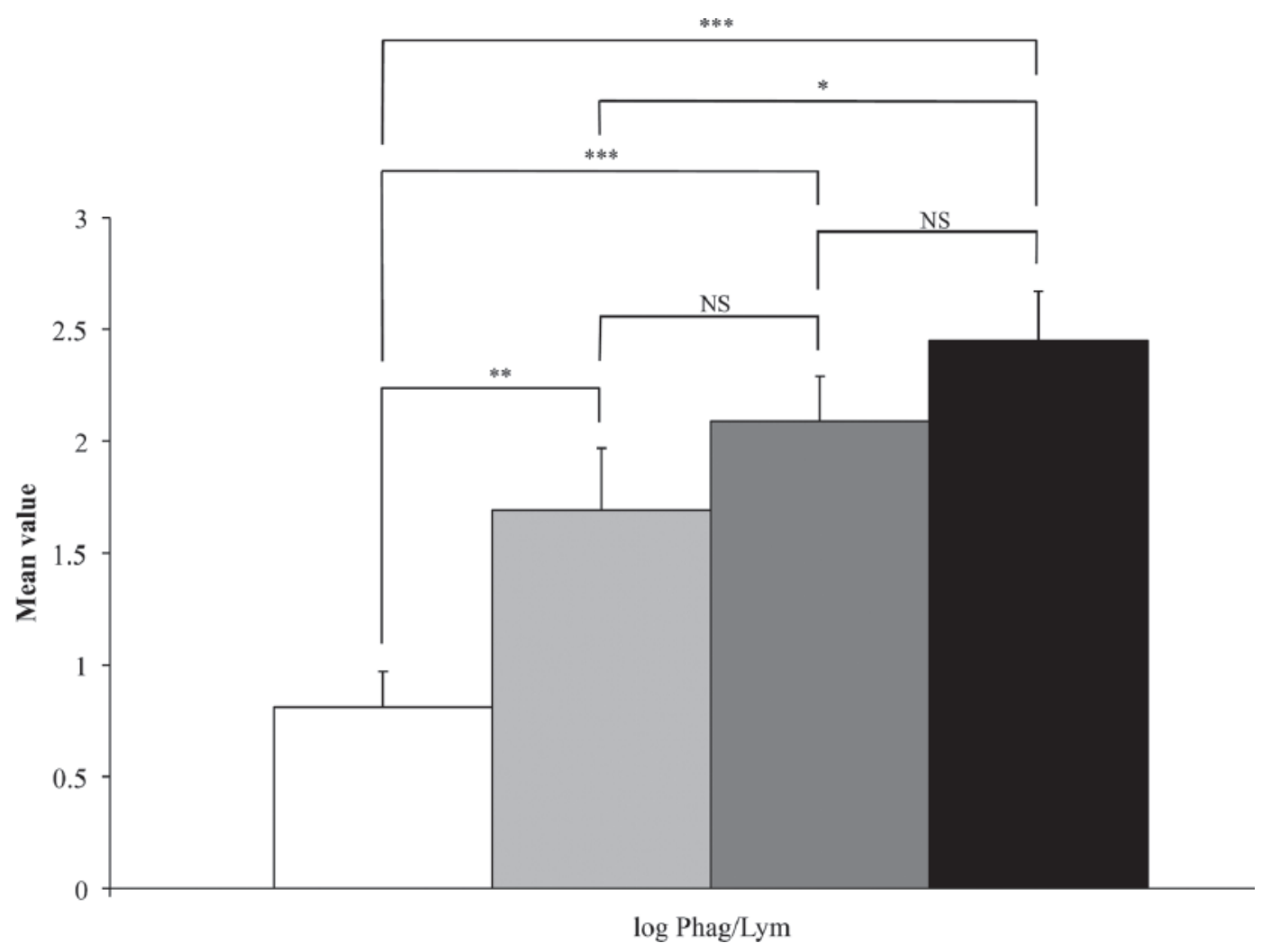

Figure 4. Comparison of mean values of the variable log Phag/Lym (logarithmic phagocyte:lymphocyte ratio) in milk of udder quarters with different health status. All 188 udder quarters analyzed were classified into groups N, LM, UM, and M (group N = empty bars, SCC $\leq 100,000$ cells $/ \mathrm{mL}$ and culture-negative, $\mathrm{n}=96$; group $\mathrm{LM}=$ light gray bars, $\mathrm{SCC} \leq 100,000$ cells $/ \mathrm{mL}$ and culture-positive, $\mathrm{n}=15 ;$ group $\mathrm{UM}=$ dark gray bars, $\mathrm{SCC}>100,000$ cells $/ \mathrm{mL}$ and culture-negative, $\mathrm{n}=47$; group $\mathrm{M}=$ black bars, $\mathrm{SCC}>100,000$ cells $/ \mathrm{mL}$ and culture-positive, $\mathrm{n}=30$ ). $\mathrm{N}=$ normal secretion; $\mathrm{LM}=$ latent mastitis; $\mathrm{UM}=$ unspecific mastitis; $\mathrm{M}=$ mastitis. Data are expressed as mean $\pm \mathrm{SEM} ;{ }^{* * *} P<0.001 ;{ }^{* *} P$ $<0.01 ;{ }^{*} P<0.05 ; \mathrm{NS}=P>0.05$. 
the only variable that involved both cell populations statistically influenced by health groups but excluded macrophages.

\section{CONCLUSIONS}

Differential cell counting can detect changes in the relative cell populations in milk without an increase in total cell number, thus identifying inflammatory processes in quarters otherwise considered healthy. This information could be particularly useful when control programs for contagious milk pathogens are being applied. In the present study, we considered mammary quarters with or without natural occurring infections to established single or combined variables capable to identify healthy and inflamed quarters. Microscopic DCC was shown to be a potentially useful tool to identify cows affected by any inflammatory process of the mammary gland, with the best results being achieved using $\log$ PMNL:Lym as variable. Further studies are needed to determine and validate the cut-off values to be applied in the dairy herd.

\section{ACKNOWLEDGMENTS}

We thank Debbie Asion (Advanced Animal Diagnostics, Durham, NC) for technical assistance in slide evaluation. We also thank the 3 dairy farmers for their cooperation.

\section{REFERENCES}

Bansal, B. K., J. Hamann, N. T. Grabowski, and K. B. Singh. 2005. Variation in the composition of selected milk fraction samples from healthy and mastitic quarters, and its significance for mastitis diagnosis. J. Dairy Res. 72:144-152.

Coles, E. H. 1974. Leukocytes. Pages 40-98 in Veterinary Clinical Pathology. 2nd ed. W. B. Saunders Co., Philadelphia, PA.

Dosogne, H., F. Vangroenweghe, J. Mehrzad, A. M. Massart-Leen, and C. Burvenich. 2003. Differential leukocyte count method for bovine low somatic cell count milk. J. Dairy Sci. 86:828-834.

Dulin, A. M., M. J. Paape, and B. T. Weinland. 1982. Cytospin centrifuge in differential counts of milk somatic cells. J. Dairy Sci. 65:1247-1251.

DVG (German Veterinary Society). 2002. Leitlinien zur Bekämpfung der Mastitis als Bestandsproblem. DVG, Giessen, Germany.

Harmon, R. J. 1994. Symposium: Mastitis and genetic evaluation for somatic cell count. J. Dairy Sci. 77:2103-2112.

Hill, A. W., A. L. Shears, and K. G. Hibbitt. 1978. The elimination of serum-resistant Escherichia coli from experimentally infected single mammary glands of healthy cows. Res. Vet. Sci. 25:89-93.

Hogan, J., and K. L. Smith. 2003. Coliform mastitis. Vet. Res. $34: 507-519$.

Hogan, J. S., R. N. Gonzales, R. J. Harmon, S. C. Nickerson, S. P. Oliver, J. W. Pankey, and K. L. Smith. 1999. Laboratory Handbook on Bovine Mastitis. Rev. ed. National Mastitis Council Inc., Madison, WI.

International Dairy Federation (IDF). 2006. Staphylococcus aureus intramammary infections. Bulletin no. 408. IDF, Brussels, Belgium.
Kehrli, M. E., and D. E. Shuster. 1994. Factors affecting milk somatic cells and their role in health of the bovine mammary gland. J. Dairy Sci. 77:619-627.

Koess, C., and J. Hamann. 2008. Detection of mastitis in the bovine mammary gland by flow cytometry at early stages. J. Dairy Res. $75: 225-232$.

Koskinen, M. T., J. Holopainen, S. Pyörälä, P. Bredbacka, A. Pitkälä, H. W. Barkema, R. Bexiga, J. Roberson, L. Sølverød, R. Piccinini, D. Kelton, H. Lehmusto, S. Niskala, and L. Salmikivi. 2009. Analytical specificity and sensitivity of a real-time polymerase chain reaction assay for identification of bovine mastitis pathogens. J. Dairy Sci. 92:952-959.

Lee, C. S., F. B. P. Wooding, and P. Kemp. 1980. Identification properties and differential counts of cell populations using electron microscopy of dry cow secretions, colostrums and milk from normal cows. J. Dairy Res. 47:39-50.

Leitner, G., M. Chaffer, O. Krifucks, A. Glickman, E. Ezra, and A. Saran. 2000a. Milk leucocyte populations in heifers free of udder infection. J. Vet. Med. B Infect. Dis. Vet. Public Health 47:133138.

Leitner, G., R. Eligulashvily, O. Krifucks, S. Perl, and A. Saran. 2003. Immune cell differentiation in mammary gland tissues and milk of cows chronically infected with Staphylococcus aureus. J. Vet. Med. B Infect. Dis. Vet. Public Health 50:45-52.

Leitner, G., E. Shoshani, O. Krifucks, M. Chaffer, and A. Saran. 2000b. Milk leucocyte populations patterns in bovine udder infection of different aetiology. J. Vet. Med. B Infect. Dis. Vet. Public Health 47:581-589.

Lindmark-Mansson, H., C. Branning, G. Alden, and M. Paulsson. 2006. Relationship between somatic cell count, individual leucocyte populations and milk components in bovine udder quarter milk. Int. Dairy J. 16:717-727.

Miller, R. H., M. J. Paape, and L. A. Fulton. 1991. Variation in milk somatic cells of heifers at first calving. J. Dairy Sci. 74:174-179.

Newbould, F. H. S., and F. K. Neave. 1965. The recovery of small numbers of Staphylococcus aureus infused into the bovine teat cistern. J. Dairy Res. 32:157-162.

Nickerson, S. C. 1989. Immunological aspects of mammary involution. J. Dairy Sci. 72:1665-1678.

Oliver, S. P., J. S. Hogan, B. M. Jayarao, and W. E. Owens. 2004. Microbiological Procedures for the Diagnosis of Bovine Udder Infection and Determination of Milk Quality. 4th ed. National Mastitis Council Inc., Verona, WI.

Oviedo-Boyso, J., J. J. Valdez-Alarcón, M. Cajero-Juárez, A. OchoaZarzosa, J. E. López-Meza, A. Bravo-Patiño, and V. M. Baizabal-Aguirre. 2007. Innate immune response of bovine mammary gland to pathogenic bacteria responsible for mastitis. J. Infect. 54:399-409.

Paape, M., J. Mehrzad, X. Zhao, J. Detilleux, and C. Burvenich. 2002 Defense of the bovine mammary gland by polymorphonuclear neutrophil leukocytes. J. Mammary Gland Biol. Neoplasia 7:109-121.

Paape, M. J., D. D. Bannerman, X. Zhao, and J.-W. Lee. 2003. The bovine neutrophil: Structure and function in blood and milk. Vet. Res. 34:597-627.

Paape, M. J., W. P. Wergin, A. J. Guidry, and R. E. Pearson. 1979. Leukocytes - Second line of defense against invading mastitis pathogens. J. Dairy Sci. 62:135-153.

Park, Y. H., L. K. Fox, M. J. Hamilton, and W. C. Davis. 1992. Bovine mononuclear leukocyte subpopulations in peripheral blood and mammary gland secretions during lactation. J. Dairy Sci. 75:998-1006.

Pillai, S. R., E. Kunze, L. M. Sordillo, and B. M. Jayarao. 2001. Application of differential inflammatory cell counts as a tool to monitor udder health. J. Dairy Sci. 84:1413-1420.

Pyörälä, S. 2003. Indicators of inflammation in the diagnosis of mastitis. Vet. Res. 34:565-578.

Riollet, C., P. Rainard, and B. Poutrel. 2001. Cell subpopulations and cytokine expression in cow milk in response to chronic Staphylococcus aureus infection. J. Dairy Sci. 84:1077-1084.

Rivas, A. L., F. W. Quimby, J. Blue, and O. Coksaygan. 2001. Longitudinal evaluation of bovine mammary gland health status by 
somatic cell counting, flow cytometry, and cytology. J. Vet. Diagn. Invest. 13:399-407.

Sarikaya, H., C. Prgomet, M. W. Pfaffl, and R. M. Bruckmaier. 2004. Differentiation of leukocytes in bovine milk. Milchwissenschaft 59:586-589.

Sarikaya, H., C. Werner-Misof, M. Atzkern, and R. M. Bruckmaier. 2005. Distribution of leucocyte populations, and milk composition, in milk fractions of healthy quarters in dairy cows. J. Dairy Res. $72: 486-492$.

Schröder, A. C., and J. Hamann. 2005. The influence of technical factors on differential cell count in milk. J. Dairy Res. 72:153-158.

Schwarz, D., U. S. Diesterbeck, S. Koenig, K. Bruegemann, K. Schlez, M. Zschoeck, W. Wolter, and C.-P. Czerny. 2011a. Microscopic differential cell counts in milk for the evaluation of inflammatory reactions in clinically healthy and subclinically infected bovine mammary glands. J. Dairy Res. 78:448-455.

Schwarz, D., U. S. Diesterbeck, S. Koenig, K. Bruegemann, K. Schlez, M. Zschoeck, W. Wolter, and C.-P. Czerny. 2011b. Flow cytometric differential cell counts in milk for the evaluation of inflammatory reactions in clinically healthy and subclinically infected bovine mammary glands. J. Dairy Sci. 94:5033-5044.

Sears, P. M., B. S. Smith, P. B. English, P. S. Herer, and R. N. Gonzalez. 1990. Shedding pattern of Staphylococcus aureus from bovine intramammary infections. J. Dairy Sci. 73:2785-2789.
Sladek, Z., and D. Rysanek. 2009. Expression of macrophage CD44 receptor in the course of experimental inflammatory response of bovine mammary gland induced by lipopolysaccharide and muramyl dipeptide. Res. Vet. Sci. 86:235-240.

Sordillo, L. M., and S. C. Nickerson. 1988. Morphometric changes in the bovine mammary gland during involution and lactogenesis. Am. J. Vet. Res. 49:1112-1120.

Sordillo, L. M., K. Shafer-Weaver, and D. DeRosa. 1997. Immunobiology of the mammary gland. J. Dairy Sci. 80:1851-1865.

Sordillo, L. M., and K. L. Streicher. 2002. Mammary gland immunity and mastitis susceptibility. J. Mammary Gland Biol. Neoplasia 7:135-146.

Targowski, S. P. 1983. Role of immune factors in protection of mammary gland. J. Dairy Sci. 66:1781-1789.

Vangroenweghe, F., H. Dosogne, and C. Burvenich. 2002. Composition and milk cell characteristics in quarter milk fractions of dairy cows with low cell count. Vet. J. 164:254-260.

Wolfinger, R., and M. O'Connell. 1993. Generalized linear mixed models: A pseudo-likelihood approach. J. Statist. Comput. Simulation 48:233-243.

Zecconi, A., R. Piccinini, A. Zepponi, and G. Ruffo. 1997. Recovery of Staphylococcus aureus from centrifuged quarter milk samples. J. Dairy Sci. 80:3058-3063. 